\title{
Driveway Moments and Decoy Stories
}

\section{Moral Injury in Medicine}

Jaime-Dawn E. Twanow, MD

Neurology ${ }^{\circledR}$ 2021;96:1002-1003. doi:10.1212/WNL.0000000000011759

For there may be no answer

and you will know too little again

or there will be an answer and you will know too much forever
Correspondence

Dr. Twanow

jaime.twanow@

nationwidechildrens.org
-John Stone, $\mathrm{MD}^{1}$

In this age of podcasts and curated Internet radio, most of us have experienced a "driveway moment." A term coined by NPR (National Public Radio), these occur when the story you are listening to is so compelling that you linger in your car to hear the conclusion. I have savored many driveway moments, but only one prompted a personal realization.

In "Act Two: The Real Decoy" from the podcast This American Life, Michael Pitre describes the evolution of a coping mechanism perfected after multiple tours in Iraq. Uncomfortable answering probing questions, Pitre developed the tactic of pivoting to prepackaged humorous anecdotes, such as recalling the escapades of the platoon's pet scorpion Fred. His "greatest hits" guaranteed a laugh and were preferred to serious insights, such as the impossible choice a nighttime scorpion sting created for local families: violating curfew or watching their child die.

One night, a close friend made a flippant comment about the casualties of the war in Iraq. Incensed by his friend's lack of regard for the loss of American and Iraqi lives, Pitre lost his temper. After his outburst, Pitre recognized that if he had been honest about his fear and grief, his loved ones would have approached him with the respect his service deserved. His decoy stories were both a symptom and the cause of his sense of isolation. ${ }^{2}$

That night in my driveway, I had my own moment of clarity. Like many physicians, I can find the shift to home life difficult. I realized that when I am unable to shed the burden of a grim day, I buffer myself and protect the psyche of my loved ones by deploying my own decoy stories.

When people learn you work in pediatrics, the impression that they have met a "carefree baby doctor" brings a certain light to their eyes. Few things snuff out that glimmer like hearing the additional words that summate my job: "neurologist," "epilepsy," and "pediatric intensive care unit." Luckily, in pediatrics, we have access to a never-ending arsenal of HIPAA-compliant decoy stories. Chuckling over dinner that my patient quit track and field because he has "couch legs" is preferable to seeing my grief reflected in my family's eyes. Thus, I refrain from reviewing my heart-wrenching discussion with the father who found his 2-year-old floating, lifeless, in his neighbor's pool. Recounting a mother's refusal of a video telehealth visit because she "was not going to put on a bra today" will keep any conversation rolling. It also starkly contrasts the suffering I would cause my loved ones if I recapped the anguish of a family care conference detailing the devastating injuries mom's boyfriend inflicted on her 4-month-old while she was getting groceries. (Details of these sadly common stories have been changed to protect patient privacy.)

Decoy stories are only one expression of the psychosocial impact of distressing events. Over the past decade, a new concept has emerged known as moral injury. ${ }^{3}$ Occurring when there is a betrayal of what is believed to be right, by an authority or oneself in a high-stakes situation, 
moral injury has overlapping features but is distinct from posttraumatic stress disorder (PTSD). ${ }^{4,5}$ Broadly, PTSD is triggered by the physiologic responses to stressful events, as opposed to the psychological struggles of "reconciling the gap between what happened with what should have happened" that leads to moral injury. ${ }^{6,7}$

From a medical perspective, the discussions of moral injury by Litz et al. ${ }^{8}$ and elaborated by Murray and Gidwani ${ }^{5}$ are the most poignant. They contend that moral injury may occur when physicians fail to prevent harm or witness firsthand the trauma and acts of violence of humans towards each other. Physicians suffering from moral injury may experience psychological and mood concerns and a sense of isolation that can be followed by social and work issues. ${ }^{6}$

Recognition and understanding of moral injury, established in the military with a validated screening tool, ${ }^{9}$ is resonating throughout medicine, with calls for research, medicinespecific screening tools, and preemptive measures., ${ }^{70,11}$ Management recommendations overlap with those for PTSD and burnout, ideally serving to remind morally injured physicians of their purpose, and that others may be experiencing similar challenges. ${ }^{12}$

Following my driveway moment, I have started to approach transitioning from work to life with the operations center mantra recalled by Pitre: "What do I know, who needs to know it, and have I told them?"2 Some days, it is helpful to admit to my loved ones that work is weighing on me. However, when my 4-year-old daughter innocently inquires if I "gave the babies their pacifiers so they didn't cry," it is enough to simply reassure her that I also swaddled them in blankets. I have come to appreciate that decoy stories are not solely a diversion. Aptly timed, they can spark and share joy, and serve as a personal reminder of my love of humanity and medicine.

The practice of medicine is an art, not a trade; a calling, not a business; a calling in which your heart will be exercised equally with your head.

$$
\text { —Sir William Osler, } \mathrm{MD}^{13}
$$

\section{References}

1. Stone J. On doctoring, 2nd ed. Simon \& Schuster; 1995:448.

2. Foo S. The real decoy. In: Glass I, ed. This American Life Podcast Feed; 2016.

3. Talbot SG, Dean W. Physicians aren't "burning out": they're suffering from moral injury. In: KevinMDcom blog; June 19, 2018. Available at: statnews.com/2018/07/ 26/physicians-not-burning-out-they-are-suffering-moral-injury/. Accessed June 19, 2020.

4. Shay J. Moral injury. Psychoanalytic Psychol 2014;31:182-191.

5. Murray E, Gidwani S. Posttraumatic stress disorder in emergency medicine residents: a role for moral injury? Ann Emerg Med 2018;72:322-323.

6. Jinkerson JD. Defining and assessing moral injury: a syndrome perspective. Traumatology 2016;22:122-130.

7. Kopacz MS, Ames D, Koenig HG. It's time to talk about physician burnout and moral injury. Lancet Psychiatry 2019;6:e28.

8. Litz BT, Stein N, Delaney E, et al. Moral injury and moral repair in war veterans: a preliminary model and intervention strategy. Clin Psychol Rev 2009;29:695-706.

9. Nash WP, Marino Carper TL, Mills MA, Au T, Goldsmith A, Litz BT. Psychometric evaluation of the moral injury events scale. Mil Med 2013;178:646-652.

10. Kopacz MS, Lockman J, Lusk J, et al. How meaningful is meaning-making. New Ideas Psychol 2019;54:76-81.

11. Roycroft M, Wilkes D, Pattani S, Fleming S, Olsson-Brown A. Limiting moral injury in healthcare professionals during the COVID-19 pandemic. Occup Med Epub 2020 May 19.

12. Vanyo LZ. In reply. Ann Emerg Med 2018;72:323.

13. Osler W. Aequanimitas “The Master-word in Medicine." 1914;475. 


\title{
Neurology
}

\author{
Driveway Moments and Decoy Stories: Moral Injury in Medicine \\ Jaime-Dawn E. Twanow \\ Neurology 2021;96;1002-1003 Published Online before print February 26, 2021 \\ DOI 10.1212/WNL.0000000000011759
}

This information is current as of February 26, 2021

\section{Updated Information \&} Services

References

Subspecialty Collections

Permissions \& Licensing

Reprints including high resolution figures, can be found at: http://n.neurology.org/content/96/21/1002.full

This article cites 8 articles, 0 of which you can access for free at: http://n.neurology.org/content/96/21/1002.full\#ref-list-1

This article, along with others on similar topics, appears in the following collection(s):

Professional conduct and ethics

http://n.neurology.org/cgi/collection/professional_conduct_and_ethics

Information about reproducing this article in parts (figures,tables) or in its entirety can be found online at:

http://www.neurology.org/about/about_the_journal\#permissions

Information about ordering reprints can be found online:

http://n.neurology.org/subscribers/advertise

Neurology ${ }^{\circledR}$ is the official journal of the American Academy of Neurology. Published continuously since 1951, it is now a weekly with 48 issues per year. Copyright @ 2021 American Academy of Neurology. All rights reserved. Print ISSN: 0028-3878. Online ISSN: 1526-632X.

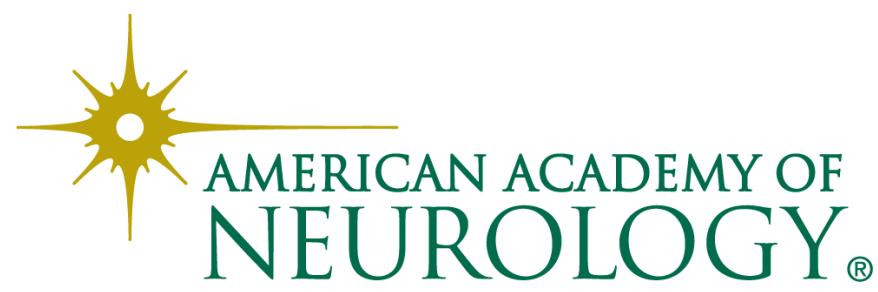

